\title{
Studi Komparasi Desain Mata Pisau Pencacah Eceng Gondok
}

\author{
Hasni Ina ${ }^{1)}$, Evi Sunarti Antu ${ }^{2}$, Yunita Djamalu ${ }^{3)}$ \\ 1,2,3) Program Studi Mesin dan Peralatan Pertanian, Politeknik Gorontalo, Jl. Muchlis Rahim, Desa Panggulo \\ Barat, Kec. Botupingge, Kab. Bone Bolango, Gorontalo, Indonesia \\ e-mail: hasnihasinina@gmail.com
}

\begin{abstract}
ABSTRAK
Eceng gondok merupakan salah satu tanaman air yang banyak tumbuh di sungai, pematang sawah atau waduk. Keberadaan tanaman ini lebih sering dianggap sebagai gulma air yang merugikan manusia. Penelitian ini merupakan penelitian studi komparasi berdasarkan hasil penelitian terdahulu untuk mendapatkan desain mata pisau dan hasil cacahan dari mesin pencacah eceng gondok. Penelitian ini bertujuan untuk mengetahui pengaruh bentuk desain mata pisau terhadap hasil cacahan dari beberapa mesin pencacah Eceng Gondok. Metode yang digunakan dalam penelitian ini adalah membandingkan beberapa mesin pencacah eceng gondok dari penelusuran referensi. Penelusuran referensi dilakukan melalui studi pustaka yaitu dengan mencari informasi berupa pengumpulan data dari internet dan beberapa mesin yang telah ada di laboratorium mesin dan peralatan pertanian. Berdasarkan hasil studi diketahui bahwa untuk pembuatan pupuk organik, mesin pencacah eceng gondok harus didesain dengan meggunakan mata pisau tipe blender dan melakukan pengaturan pada plat penahan. Hal ini dimaksudkan agar hasil cacahan yang diperoleh dapat dimanfaatkan sesuai dengan kebutuhannya, dimana ukuran cacahan eceng gondok untuk pembuatan pupuk organik berkisar $1,5 \mathrm{~cm}$.
\end{abstract}

Kata Kunci: eceng gondok, mata pisau, hasil cacahan, pupuk organik

\begin{abstract}
Eceng gondok (Eichornia crassipes) is one of the aquatic plants that grows in rivers, rice fields or reservoirs. The existence of this plant is more often considered as an aquatic weed that harms humans. This research is a comparative study based on the results of previous studies to obtain the blade design and chopping results from the eceng gondok chopping machine. This study aims to determine the effect of the shape of the blade design on the chopping results of several eceng gondok chopping machines. The method used in this study was to compare some thrasher hyacinth from the reference search. Reference search is done through literature study, namely by looking for information in the form of data collection from the internet and several machines that already exist in the agricultural machinery and equipment laboratory. Based on the results of the study, it is known that for the manufacture of organic fertilizer, the eceng gondok chopping machine must be designed using a blender-type blade and adjusting the retaining plate. It is intended that the chopped results obtained can be utilized according to their needs, where the size of the chopped eceng gondok for the manufacture of organic fertilizer is around $1.5 \mathrm{~cm}$.
\end{abstract}

Keywords: eceng gondok, blade, pieced, organic fertilizer 


\section{PENDAHULUAN}

Eceng Gondok merupakan salah satu tanaman air yang banyak tumbuh di sungai, pematang sawah atau waduk (Gambar 1). Keberadaan tanaman ini lebih sering dianggap sebagai gulma air yang merugikan manusia. Gulma ini bisa dimanfaatkan untuk makanan ternak, namun dalam pemanfaatannya harus dipertimbangkan karena kandungan serat kasar yang tinggi (Marlina \& Asker, 2001). Untuk mengatasi hal tersebut perlu dilakukan pengolahan, misalnya dengan cara pencacahan. Eceng Gondok juga mempunyai sistem perakaran yang luas. Hal ini sangat baik untuk media pendukung pertumbuhan hemiselulosa yang sangat besar sehingga baik dimanfaatkan menjadi sumber energi. Salah satu alternative Pemanfaatan Eceng Gondok adalah untuk pembuatan pupuk cair. Pupuk organik cair adalah pupuk berbahan dasar dari hewan dan tumbuhan yang mengalami fermentasi dimana bentuk produknya berupa cairan.

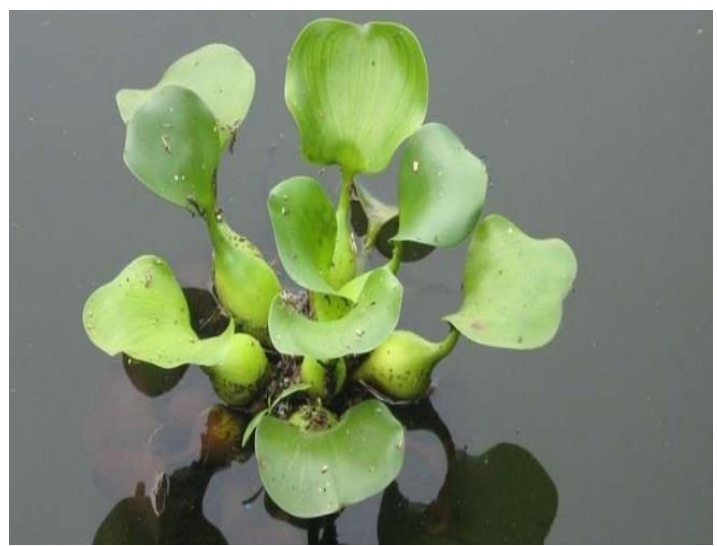

Gambar 1. Eceng Gondok (Anonim, 2019)

Eceng Gondok dengan mudah menyebar melalui saluran air ke badan air lainya (Iksan, 2019). Komposisi kimia dari Eceng Gondok berupa bahan organik sebesar 78,47\%, C organik 21,23\%, N total $0,28 \%$, $\mathrm{P}$ total $0,0011 \%$, dan $\mathrm{K}$ total $0,016 \%$. Komposisi inilah yang menjadikan Eceng Gondok berpotensi untuk dimanfaatkan sebagai pupuk organik cair yang diperlukan tanaman untuk tumbuh (Rozaq Kristanto dan Novianto, 2003). Hasil cacahan yang digunakan untuk pembuatan pupuk cair dari Eceng Gondok ialah hasil cacahan yang halus selanjutnya proses permentasi untuk dijadikan pupuk cair.

Proses pencacahan secara manual dilakukan dengan menggunakan kekuatan tangan manusia, kegiatan pencacahan merupakan kegiatan yang paling banyak menguras tenaga dan membutuhkan waktu yang lama untuk pencacahan, dalam proses pencacahan secara manual juga akan membutuhkan tenaga kerja yang banyak. Penelitian ini akan mengkomparasikan beberapa hasil penelitian untuk mendapatkan desain mata pisau dan hasil cacahan Eceng Gondok yang sangat efisien untuk pembuatan pupuk cair.

\section{METODE PENELITIAN}

\section{Jenis Penelitian}

Penelitian ini merupakan penelitian yang menggunakan studi komparasi beberapa mesin/alat pecacah eceng gondok. Analisis yang dilakukan dalam penelitian ini berupa analisis kualitatif deskriptif berkaitan kinerja mesin/alat pencacah eceng gondok berdasarkan tipe dan jenis mata pisau yang digunakan.

\section{Sumber Data}

Sebagaimana metode penelitian ini termasuk dalam studi pustaka atau literature, maka data berupa informasi diperoleh dari berbagai sumber termasuk internet berkaitan dengan alat/mesin yag digunakan untuk mencacah eceng gondok.

\section{Tahapan Penelitian}

Adapun langkah-langkah dalam penelitian adalah sebagai berikut:

1. Tahap awal.

Tahap awal untuk proses memulai dalam mengelompokan dan pemilihan suatu masalah yang akan diteliti sehingga dalam proses memulai penelitian akan diketahui persiapan apa saja yang akan di buat.

2. Penentuan sumber data.

Hal ini dilakukan melalui strategi penyelidikan penelitian terdahulu dengan melibatkan beberapa pemeriksaan yang sangat detail dan rinci berkaitan dengan alat pencacah Eceng Gondok.

3. Pengambilan data.

Pengambilan data dilakukan dengan mengambil data dengan melalui studi pustaka, mencari informasi berupa pengumpulan data mengenai media internet, jurnal dan membaca buku.

4. Pengolahan data.

Yaitu mengolah data untuk dijadikan studi komparasi beberapa alat pencacah Eceng Gondok dengan mengolah data sebaik mungkin. 
5. Analisis Data

Analisis data penelitian dilakukan dengan memfokuskan pada hasil cacahan eceng gondok berdasarkan desain mata pisau yang digunakan.

6. Kesimpulan

Penarikan kesimpulan dimaksudkan untuk memperoleh informasi berkaitan indikatorindikator yang baik dalam merancang sebuah alat/mesin yang digunakan untuk mencacah eceng gondok. Termasuk aplikasi hasil cacahan eceng gondok seperti pembuatan pupuk organik.

\section{HASIL DAN PEMBAHASAN}

Berdasarkan Tabel 1 diketahui bahwa desain mata pisau tipe blender dapat meghasilkan cacahan yang halus dengan ukuran $1,5 \mathrm{~cm}$, sehingga pada proses pengulangan mencacaha mata pisau tipe blender tetap memutar namun plat penahan yang diatur sesuai hasil cacahan yang diinginkan. Mata pisau dengan tipe ini mata pisau akan mencacah
Eceng Gondok dengan cara diputar-putarkan oleh 3 buah pisau, dengan jarak antar pisau $4 \mathrm{~cm}$. Hasil cacahan dengan ukuran 1,5 dimaksudkan untuk pemanfaatan pembuatan pupuk organik.

\section{Jenis Mata Pisau Mesin Pencacah Eceng Gondok}

Beberapa jenis mata pisau yang digunakan untuk mencacah eceng gondok dapat dilihat pada Gambar 2, 3, dan 4.

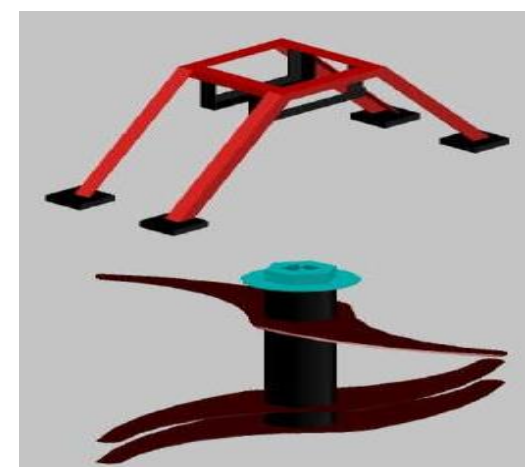

Gambar 2. Mata Pisau Tipe Blender (Iksan, 2019)

Tabel 1. Hasil Kajian Referensi Mesin Pencacah Eceng Gondok

\begin{tabular}{|c|c|c|c|}
\hline \multirow{2}{*}{$\begin{array}{l}\text { Indikator } \\
\text { Kajian }\end{array}$} & \multicolumn{3}{|c|}{ Referensi } \\
\hline & (Iksan, 2019) & (Pratama, 2013) & (Prasetyo, 2020) \\
\hline Mata Pisau & $\begin{array}{ll}\text { - } & \text { Tipe blender } \\
\text { - } & \text { Terdiri dari } 3 \text { buah } \\
\text { - } & \text { Posisi vertikal } \\
\text { - } & \text { Dimensi } 380 \times 120 \mathrm{~mm} \\
\text { - } & \text { Ketebalan } 3 \mathrm{~mm}\end{array}$ & $\begin{array}{ll}\text { - } & \text { Tipe siku dengan sudut } \\
& 10 \text { derajat } \\
\text { - } & \text { Terdiri dari } 10 \text { buah } \\
\text { - } & \text { Posisi vertikal } \\
\text { - } & \text { Memiliki diamter } \\
& \text { tabung potong } 220 \mathrm{~mm} \\
\text { - } & \text { mata pisau terbuat dari } \\
& \text { stainless steel. }\end{array}$ & $\begin{array}{l}\text { - Tipe silinder berpaku } \\
\text { - Memiliki silinder } \\
\text { pencacah } 78 \text { buah dan } \\
\text { paku penahan } 36 \text { buah } \\
\text { - Posisi vertikal } \\
\text { - Pisau pencacah memilik } \\
\text { diamter } 8 \mathrm{~cm} \\
\text { - Jarak antar paku } \\
\text { penahan dengan paku } \\
\text { silinder } 2 \mathrm{~cm}\end{array}$ \\
\hline $\begin{array}{l}\text { Prinsip Kerja } \\
\text { Alat }\end{array}$ & $\begin{array}{l}\text { Bahan yang masuk ke } \\
\text { dalam inlet akan masuk ke } \\
\text { tabung pencacah } \\
\text { didalamnya terdapat } 3 \\
\text { buah pisau, pisau tersebut } \\
\text { digerakan oleh penggerak } \\
\text { menggunakan motor listrik } \\
\text { yang penyaluran dayanya } \\
\text { langsung ke poros pemutar } \\
\text { pisau. }\end{array}$ & $\begin{array}{l}\text { Cara Kerjanya yaitu motor } \\
\text { listrik melalui transmisi V- } \\
\text { belt memutarkan blade } \\
\text { yang terdapat pada tabung } \\
\text { pemotongan dan mencacah } \\
\text { eceng gondok. }\end{array}$ & $\begin{array}{l}1 \mathrm{~kg} \text { Eceng gondok yang } \\
\text { dicacah akan masuk dalam } \\
\text { inlet dan masuk ke tabung } \\
\text { pemotong, didalamnya } \\
\text { terdapat mata pisau paku } \\
\text { penahan } 36 \text { dan mata pisau } \\
\text { pencacah } 78 \text {. Digerakan } \\
\text { oleh dinamo. }\end{array}$ \\
\hline $\begin{array}{l}\text { Pengaplikasian } \\
\text { Eceng Gondok }\end{array}$ & $\begin{array}{l}\text { Untuk pembuatan pupuk } \\
\text { organik. }\end{array}$ & $\begin{array}{l}\text { Digunakan untuk pakan } \\
\text { itik. }\end{array}$ & $\begin{array}{l}\text { Digunakan untuk pakan } \\
\text { ternak }\end{array}$ \\
\hline $\begin{array}{l}\text { Kapasitas Hasil } \\
\text { Cacahan }\end{array}$ & - & $72 \mathrm{~kg} / \mathrm{jam}$ & $16,6 \mathrm{~kg} / \mathrm{jam}$ \\
\hline Ukuran Cacahan & $1,5 \mathrm{~cm}$ & - & - \\
\hline
\end{tabular}




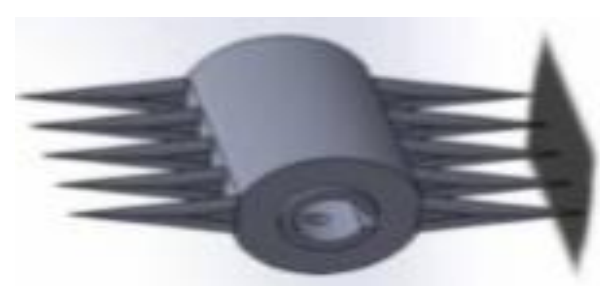

Gambar 3. Mata Pisau Berbentuk 10 Derajat (Pratama, 2013)

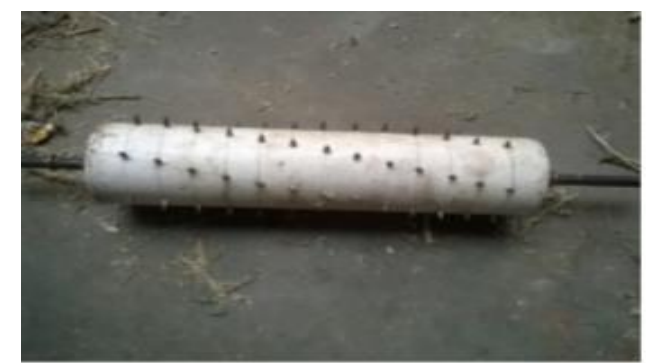

Gambar 4.3 Mata Pisau Berbentuk Silinder Berpaku (Prasetyo, 2020)

Desain mata pisau tipe blender mampu menghasilkan cacahan dengan ukuran $1,5 \mathrm{~cm}$ (halus). Sementara desain mata pisau tipe 10 derajat ini mampu menghasilkan cacaha sebanyak 1,2 $\mathrm{kg} /$ menit eceng gondok dengan berat $1 \mathrm{~kg}$ untuk hasil cacahan tidak di cantumkan dalam hasil penelitian. Adapun mesin pencacah dengan desain mata pisau berbentuk silinder berpaku ini mampu melakukan pencacahan sebanyak $16,6 \mathrm{~kg} / \mathrm{jam}$.

Berdasarkan perbandingan jenis mata pisau dan hasil cacahan yang diperoleh oleh masing-masing mesin pencacah eceng gondok diketahui bahwa pengolahan dan pencacahan eceng gondok disesuaikan dengan aplikasi hasil cacahannya. Hasil cacahan dengan ukuran $1,5 \mathrm{~cm}$ diperoleh oleh mesin pencacah dengan mata pisau tipe blender. Dimensi hasil cacahan ini sangat cocok untuk pembuatan pupuk organik, baik padat maupun cair. Hasil cacahan menggunakan mata pisau tipe ini dapat disesuaikan dengan cara mengatur plat penahan. Artinye, ketika hasil cacahan yang diinginkan sudah sesuai maka plat penahan dilepas.

Untuk mata pisau tipe silinder berpaku mampu mencacah eceng gondok yang dapat digunakan untuk pakan ternak, terutama itik. Hasil cacahan dengan mata pisau tipe ini memiliki ukuran yang lebih kasar dibandingkan mata pisau tipe blender. Artinya, penggunaan hasil cacahan mata pisau tipe ini tidak cocok untuk pembuatan pupuk organik. Hal ini karena akan memerlukan waktu yang cukup lama saat pembusukan (pengubahan) eceng gondok menjadi pupuk organik. Dengan kata lain, semakin keciil ukuran eceng gondok hasil cacahan akan semakin cepat proses pembuatan pupuk organik.

\section{KESIMPULAN}

Berdasarkan uraian di atas dapat disimpulkan sebagai berikut:

1. Desain mata pisau pada mesin pencacah eceng gondok disesuaikan dengan aplikasi dan peruntukkan hasil cacahan.

2. Hasil cacahan eceng gondok dapat dimanfaatkan dalam pembuatan pupuk organik ketika eceng gondok dicacah menggunakan mesin pencacah yang dilengkapi dengan mata pisau tipe blender.

3. Ketika hasil cacahan eceng gondok dimanfaatkan untuk pakan ternak, maka eceng gondok dicacah menggunakan mesin pencacah yang dilengkapi dengan mata pisau silinder berpaku.

4. Faktor lain yang dapat diperhatikan dalam membuat mesin pencacah eceng gondok adalah putaran yang digunakan selama pencacahan.

\section{DAFTAR PUSTAKA}

Anonim, 2019, Manfaat Eceng Gondok Untuk Pupuk. Diakses pada 2 januari 2019. Link:https://bertanidi.blogspot.com/2014/07/manfaat-encenggondok-untuk pupuk.html.https://id.wikipedia.org/wiki/Ece ng_gondok.

Daywin, F.J., D. (2008). Mesin-mesin Budidaya Pertanian di Lahan Kering. Jakarta: Graha Ilmu.

Hadisuwito, S., 2012, Membuat Pupuk Organik Cair. PT. Agro Media Pustaka: Jakarta Selatan.

Hadiutomo, 2012, Mekanisasi Pertanian. Bogor: IPB Press.

Ihwan, F., 2014, Pengujian Mesin Pencacah Hijauan Pakan (Chopper) Tipe Vertikal. Lampung Vol 4 No 1: 35-40. (14/1/2019).

Iksan, M., 2019, Rancang Bangun Mesin Pencacah Eceng Gondok unutk Pembuatan Pupuk Organik. Diakses pada tanggal 2 Juni 2019.

Kementerian Pertanian, 2011, Basis Data EksporImpor Komoditi Pertanian. Diperoleh dari website Kementerian Pertanian Republik Indonesia. 
Kristanto, B, A. Dkk., 2003, Pemanfaatan Eceng Gondok (E. crassipes) sebagai bahan pupukcair. Jurnal UNDIP.

Marlina, N., \& Askar, S., 2001, Nilail Gizi Eceng Gondok dan Pemanfaatan Sebagai Pakan ternak Non Ruminansia. Balai Penelitian Ternak Bogor. Vol. 5 No Hal 12.

Prasetyo, dkk., 2015, Rekayasa alat pencacah Eceng Gondok menggunakan siinder berpaku serta metode mencacah searah serat Eceng Gondok. Jurnal Jurnal Fisika Vol. 5 No.

Pratama, S., Andrea, R., Anwar, S., \& Rizal, P., 2013, Alat Pencacah Eceng Gondok untuk Meningkatkan Produktivitas Pakan Iitik KUR Mekar Asih.

Soenandar, M., Nur, A, M., Raharjo, A., 2010 Petunjuk Praktis Membuat Pestisida Organik. PT. Agro Media Pustaka: Jakarta Selatan diakses pada tanggal 30 desember 2019.

Taufika, R. 2011. Pengujian Beberapa Dosis Pupuk Organik Cair TerhadapPertumbuhan dan Hasil Tanaman Wortel (Doucus carota L). Jurnal Tanaman. 1 (2) : 1-10 